\title{
Foreign Aid and Quality of Governance in Developing Countries: An Econometric Case Study of South Asia and East Asia
}

\author{
Rahim M. Quazi ${ }^{1} \&$ Arshad Alam $^{1}$ \\ ${ }^{1}$ Department of Management and Marketing, College of Business, Prairie View A\&M University, Texas, USA \\ Correspondence: Rahim M. Quazi, Department of Management and Marketing, College of Business, Prairie \\ View A\&M University, Texas, USA. Tel: 1-936-261-9225. E-mail: rmquazi@ pvamu.edu
}

Received: June 16, 2015

Accepted: June 29, 2015

Online Published: August 25, 2015

doi:10.5539/ibr.v8n9p16

URL: http://dx.doi.org/10.5539/ibr.v8n9p16

\begin{abstract}
The paper investigates the effect of foreign aid on governance. Foreign aid's effect on the quality of governance remains a widely debated topic. Theory provides conflicting guidance on this and the empirical record of previous research is not conclusive and often contradictory. Our research on a sample of South Asian and East Asian countries suggests that aid can have a positive effect on governance when controlling for other country factors. The estimated results also suggest that multilateral aid has a positive effect on the quality of governance, but the effect of bilateral aid on the quality of governance is either negative or insignificant. These results have important policy implications for donor countries and multilateral institutions alike.
\end{abstract}

Keywords: foreign aid, quality of governance, South Asia, East Asia

\section{Introduction}

In the post-WWII period, foreign aid from developed countries and multilateral organizations played a significant role in the growth dynamics of developing countries. Inspired by the success of the US-led Marshall Plan in restoring economic stability in war-ravaged Europe, many foreign assistance programs were launched in this period to assist developing countries. The effect on growth in many of these aid recipient countries, however, turned out to be less than satisfactory, which has generated an intense debate among development economists about the efficacy of aid programs.

Based on the theoretical development of the 1950's and 1960's, the traditional pro-aid view holds that foreign aid complements the recipient economies' domestic resources, relieves foreign exchange constraints, transfers modern know-how, and facilitates easy access to global market-all of which contribute to positive economic growth (Chenery, 1965; Papanek, 1972). In contrast, the radical anti-aid view holds that foreign aid supplants domestic resources, worsens domestic income inequality and trade balance, funds the transfer of inappropriate technology, and in general helps sustain inefficient and corrupt governments in developing countries (Griffin \& Enos, 1970; Weisskopf, 1972). An interesting area of research has recently emerged that explores the relationship between foreign aid and the quality of governance in developing countries.

The criticality of foreign aid to the economic growth in developing countries arises from the investment deficit faced by these countries as also in the potential contribution of foreign aid in reducing market imperfections (Harms \& Lutz, 2004). In spite of significant foreign aid over the decades, however, many countries have not been able to grow out of poverty. Collier (2007), in his well discussed book, identifies four reasons or four "traps" why so many millions are still trapped in extreme poverty, one of which is the poor governance of the aid-recipient countries. The importance of governance stems from the fact that governments have a role in ensuring a macro-organizational environment in which markets can function efficiently (Dunning, 1992). The role and quality of governance/institutions has a bearing on the economic and non-economic sectors of a country and is crucial for competitiveness and innovation (Niosi, 2002), more so in a globalized economy of today. The efficiency and the efficacy of the political and legal systems provide the requisite stability and predictability for businesses to operate. They affect both domestic and foreign businesses alike, but to the extent that foreign investors have a choice they are more likely to invest in countries with good governance. Good governance can thus help make the country a more attractive destination for foreign direct investment.

A number of studies have argued that foreign aid diminishes the quality of governance in recipient countries by 
encouraging corruption and other rent seeking activities, fueling conflict between competing interest groups over access to aid funds, and diverting human resources from the public sector to aid-funded projects (Tavares, 2003; Bräutigam \& Knack, 2004; Ear, 2007; Asongu, 2013). The World Bank admits that the huge increase in foreign aid packages to developing countries has inadvertently contributed to the "opportunities of malfeasance" (World Bank, 1989, p. 27). Knack (2001) contends that increased aid-dependence offers a "crutch" to countries with poor economic policies and weak governance. It can lead countries to substitute donor resources and expertise for their own (Goldsmith, 2000). Ali and Isse (2003) concluded that foreign aid "strengthens the predatory power of the government ... and creates opportunities for the government to proliferate...".

On the other side of the debate, several studies have argued that foreign aid affects the quality of governance positively (Goldsmith, 2001; Dunning, 2004; Ear, 2007; Charron, 2011; Okada \& Samreth, 2012). These studies contend that aid can improve the quality of civil administration, boost policy and planning capacity, and strengthen central institutions. Foreign aid may alleviate revenue constraints allowing recipient governments to pay higher salaries to public sector workers, which may provide incentives for more efficient governance. Aid can also provide foreign technical assistance to build legal systems and domestic institutions boosting governance effectiveness. Furthermore, aid donors can impose pre-conditions on the recipient countries to initiate specific reforms to improve the quality of governance prior to receiving aid packages. International oversight by aid donors may also enhance accountability of recipient governments. Finally, successful foreign aid programs can contribute to overall economic growth and human development, which in turn can result in good governance. South Korea and Taiwan are good examples of how foreign aid has contributed to institution building process in East Asia, while Botswana is a good illustration of it in sub-Saharan Africa (Bräutigam \& Knack, 2004).

This study uses 1996-2013 panel data from 14 developing countries in South Asia and East Asia to analyze the impact of foreign aid on the quality of governance. The sample countries include 7 countries from South Asia (Bangladesh, Bhutan, India, Maldives, Nepal, Pakistan and Sri Lanka) and 7 countries from East Asia (Cambodia, China, Indonesia, Lao, Malaysia, Philippines and Vietnam). These countries were selected for this study as they provide a good sample of moderately to heavily aid-dependent developing countries with dubious quality of governance. The figures presented in Table A1 (Appendix) show that the global average for foreign aid/GNI (0.19\%) is significantly smaller than that of each region in the sample (S. Asia: 4.14\%, E. Asia: 3.84\%), which suggests that compared to the rest of the world both regions are highly dependent on foreign aid. The global average score for each of six indicators of governance also far exceeds the average score of each region, which suggests that both regions suffer from poor quality of governance in all six areas. The average ODA/GNI figures reveal that South Asia is slightly more aid-dependent than East Asia (4.14\% vs. 3.84\%), and the average composite governance indicators suggest that South Asia has slightly better quality of governance than East Asia $(-0.46$ vs. -0.50$)$.

The impetus for the study stems from the fact that while there are numerous studies analyzing the effect of aid on the quality of governance, none is focused exclusively on East Asia and South Asia. Although some countries from this sample have been included in other studies, by focusing exclusively on countries in this region, the study makes a unique contribution to the literature by improving our knowledge of the aid-governance dynamics in these emerging economies. Additionally, a deeper understanding of the aid-governance dynamics will assist in devising strategies to promote long-term economic efficiency of the region and indeed of developing countries in general.

The paper is structured as follows: the literature survey is followed by a section dealing with the model and methodology of the study, discussion of the results and finally conclusion.

\section{Literature Review}

A number of empirical studies have investigated the relationship between foreign aid and governance quality or some type of democratic performance outcome in the recipient countries. It has been argued that significant aid on a sustained basis may adversely affect governance. Instead of building capacity, aid may substitute for local efforts thus reducing the incentive for institution building. By making the recipient countries aid dependent, it reduces local ownership and accountability of development efforts and lowers the incentive for augmenting tax revenues (Bräutigam, 2000). Thus, Knack (2001) found a significant and negative relationship between aid and quality of governance in recipient nations; specifically, some types of aid, e.g. technical assistance, weaken bureaucratic quality and rule of law. Similarly, Bräutigam and Knack (2004) analyzed the aid-quality of governance relationship for 32 sub-Saharan countries and found a robust and negative relationship between them. The study also found that the aid donors tend to give more aid to countries with improving level of governance. 
Heckelman and Knack (2005) used data on governance quality from the Economic Freedom and found that aid dependence weakens market-liberalizing reforms. Knack and Rahman (2007) in their study on bureaucratic quality used data from the International Country Risk Guide (ICRG) for a sample of 96 countries over the 1982-2001 period and found that higher donor fragmentation (i.e. aid programs run by many donors, where each donor has a small share, and especially when multilateral aid donors have small shares) leads to diminished quality of bureaucratic services.

Foreign aid can however also lead to better governance, especially if aid is linked to improved governance and provides technical support towards good governance and generally by aiding in human development of the recipient countries (Ear, 2007). Goldsmith (2001) found that higher aid/GDP ratio is associated with higher levels of democratic performance and economic freedom in sub-Saharan Africa. Dunning (2004) found that when the sample used in Goldsmith (2001) is disaggregated into the Cold-War and post-Cold War periods, the positive relationship between aid and democratization in sub-Saharan Africa holds only in the latter period. Okada and Samreth (2012) contended that foreign aid is likely to be utilized more efficiently in low-corruption countries, which, inter alia, may improve the quality of institutions and governance. They also argued that multilateral aid is more effective in reducing corruption than bilateral aid, which is due to the fact that multilateral aid is often tied to the recipient countries' commitment to promotion of institutional quality and reduction of corruption, but bilateral aid is often dictated by geo-political strategic interest of donor countries and their historical relationships with recipient countries, regardless of institutional reforms or quality of governance in recipient countries.

A number of studies have found that foreign aid reduces corruption in recipient countries, which is an important attribute of quality of governance. Svensson (2000) used a game-theoretic rent-seeking model on panel data from 66 aid recipient countries, and found a weak, but robust negative relationship between foreign aid and corruption. Similarly, Tavares (2003) found that aid reduces corruption in his study of the impact of aid from the 11 largest OECD countries to non-OECD countries. He attributed this to the conditionality effect-aid donors can enforce strict rules and conditions on the recipient countries, thus limiting the discretion of their officials and reducing the incidence of corruption.

Ear (2007) used data from 209 countries and territories for five years (1996, 1998, 2000, 2002 and 2004) to analyze the effects of aid on quality of governance. The study used data from the Worldwide Governance Indicators (WGI) for six dimensions of governance (voice and accountability, political stability, government effectiveness, regulatory quality, rule of law, and control of corruption). A composite Governance Index, a simple un-weighted average of the six dimensions of governance, was also used. Using panel estimation methodology, the study found that aid dependence worsens only one dimension of governance (rule of law), but the statistical evidence is not very strong. The study concluded that the causal relationship between aid and quality of governance may not be very robust.

Among the recent studies, Asongu (2013) analyzed the impact of foreign aid on a broad set of institutional quality indicators using the WGI data for a sample of 52 African countries covering the period 1996-2010. Population growth, trade, democracy, public investment, legal system, religion and income level were used as exogenous variables. The results suggest that foreign aid has weakened economic governance (regulation quality and government effectiveness) and institutional governance (corruption control and rule of law) in Africa; the impact of aid on political governance (political stability and voice and accountability) was insignificant.

\section{Model, Methodology and Data}

The purpose of this study is to analyze the impact of foreign aid on the quality of governance in South Asia and East Asia. Data from 7 countries from each region i.e. a total of 14 countries for the period 1996-2013 was analyzed using panel estimation methodology. The following model was employed.

$$
\begin{aligned}
& \text { Quality of Governance }_{i, t}=\alpha+\beta_{1} \text { Foreign Aid }_{i, t}+\beta_{2} \text { Education }_{i, t}+\beta_{3} \text { Population }_{i, t} \\
& +\beta_{4} \text { Economic Development }_{i, t}+\beta_{5} \text { Colonial Legacy }_{i, t}+\beta_{6} \text { Region }_{i, t}+\varepsilon_{i, \mathrm{t}}
\end{aligned}
$$

The dependent variable is the quality of governance and the independent variables are foreign aid, education, population, economic development, colonial legacy/history and regional difference. A second version of the model where foreign aid is disaggregated into multilateral aid and bilateral aid was also estimated.

Selection of these exogenous variables was guided by the extant empirical literature. Foreign aid (as a share of national income) is the variable of interest and is included in the model. Human capital is expected to directly impact governance quality; education level, as a proxy of human capital, is thus included in the model (Heckelman \& Knack, 2005). Population growth can contribute to higher quality of governance, if economies of 
scale are associated with establishment of effective institutions (Knack, 2001; Bräutigam \& Knack, 2004; Ear, 2007). Economic development can generate tax revenues for public coffers, which can improve the quality of governance by alleviating funding constraints (Goldsmith, 2001; Knack, 2001; Bräutigam \& Knack, 2004; Dunning, 2004; Ear, 2007). The legal, judicial and other civil administration systems in countries that experienced long history of European colonialism can be different from other countries (Goldsmith, 2001; Dunning, 2004). A dummy variable has been added to account for the European colonial history of the sample countries. Finally, the quality of governance may be influenced by cultural traditions (Bräutigam \& Knack, 2004). A second dummy variable (Region) has been added to account for the cultural differences between South Asia and East Asia.

Data on quality of governance was obtained from the Worldwide Governance Indicators (WGI). The WGI indicators represent six broad dimensions of governance that are constructed with a large dataset on perceptions of governance collected from many survey institutes, think tanks, NGOs and private firms (Note 1). The WGI indicators are available for over 200 countries since 1996. The six indicators of governance quality and their definitions from the WGI dataset (WGI, 2014) are reproduced below.

i. Voice and Accountability - Reflects perceptions of the extent to which a country's citizens are able to participate in selecting their government, as well as freedom of expression, freedom of association, and a free media.

ii. Political Stability and Absence of Violence/Terrorism - Reflects perceptions of the likelihood that the government will be destabilized or overthrown by unconstitutional or violent means, including politically-motivated violence and terrorism.

iii. Government Effectiveness - Reflects perceptions of the quality of public services, the quality of the civil service and the degree of its independence from political pressures, the quality of policy formulation and implementation, and the credibility of the government's commitment to such policies.

iv. Regulatory Quality - Reflects perceptions of the ability of the government to formulate and implement sound policies and regulations that permit and promote private sector development.

v. Rule of Law - Reflects perceptions of the extent to which agents have confidence in and abide by the rules of society, and in particular the quality of contract enforcement, property rights, the police, and the courts, as well as the likelihood of crime and violence.

vi. Control of Corruption - Reflects perceptions of the extent to which public power is exercised for private gain, including both petty and grand forms of corruption, as well as "capture" of the state by elites and private interests.

On each one of these six indicators, countries are scored from -2.5 (weak quality of governance) to 2.5 (strong quality of governance), so a higher score on these indicators reflects higher quality of governance. Following Knack (2001) and Ear (2007), a composite measure of the quality of governance was computed by taking a simple average of the six indicators. Therefore, a total of seven versions of equation (1) were estimated with each of the six indicators as well as the composite indicator of governance as the dependent variable.

Data on three types of aid (total aid, multilateral aid, and bilateral aid-each as percentage of GNI), education (secondary school enrolment as a percentage of population), population (log of national population), and economic development (log of per capita GNI in current US\$) was collected from the World Development Indicators (World Bank 2014).

The literature holds that there may exist a simultaneous relationship between foreign aid and the quality of governance. To check for the presence of this relationship, Granger Causality tests were run on foreign aid and the composite quality of governance for each one of the 14 sample countries. These tests were also run for each possible pair between multilateral aid (and also bilateral aid) and the six components of governance. The Granger Causality test results revealed the presence of simultaneity between aid and governance variables (Note 2). To address this simultaneity/endogeneity problem, this study uses 5-year rolling average of lagged foreign aid, multilateral aid and bilateral aid as explanatory variables of quality of governance. The 5-year rolling average also reduces annual volatility in aid time series.

\section{Discussion of Results}

Tables 1-2 below (and Tables A2-A7 in the Appendix) report the panel model regression results. Each model is estimated with two estimation techniques-Random Effects and Feasible Generalized Least Squares (FGLS). The Random Effects method was selected over the Fixed Effects method, as the test statistics revealed strong presence of random effects in the regression equation. The diagnostics statistics also revealed the presence of autocorrelation without heteroscedasticity, which is addressed by using the FGLS method with panel-specific 
autocorrelation in homoscedastic panels (Note 3). A total of seven regression models were estimated. In the first regression, the dependent variable was the composite measure of quality of governance, followed by six models where the dependent variables are the six components of governance (voice and accountability, political stability, etc.). Each model is also re-estimated by disaggregating the total volume of foreign aid into multilateral aid and bilateral aid.

Table 1 shows that all the explanatory variables except for education are generally statistically significant in either the random effects model or FGLS model or in both the models. The effect of aggregate foreign aid on the composite measure of quality of governance appears positive and though marginally insignificant in the Random Effects model, is highly significant in the FGLS model. When total aid is disaggregated into multilateral aid and bilateral aid, it is found that multilateral aid has a positive effect on the quality of governance in both models, but the effects of bilateral aid is either negative or insignificant.

Table 1. Determinants of quality of governance (composite measure)

\begin{tabular}{|c|c|c|c|c|c|c|c|c|}
\hline & \multicolumn{2}{|c|}{ Random Effects Model } & \multicolumn{2}{|c|}{ Feasible GLS Model } & \multicolumn{2}{|c|}{ Random Effects Model } & \multicolumn{2}{|c|}{ Feasible GLS Model } \\
\hline & Coeff & Z stat & Coeff & $Z$ stat & Coeff & Z stat & Coeff & Z stat \\
\hline Aggregate Aid & 0.01 & 1.50 & 0.02 & $2.66 * *$ & & & & \\
\hline Multilateral Aid & & & & & 0.14 & $4.89 * *$ & 0.13 & $3.71 * *$ \\
\hline Bilateral Aid & & & & & -0.02 & $-1.66^{*}$ & 0.001 & 0.12 \\
\hline Population & -0.14 & $-2.03 * *$ & -0.05 & $-2.42 * *$ & -0.12 & $-1.69^{*}$ & -0.02 & -0.9 \\
\hline Tax Revenues & 0.02 & $2.31 * *$ & 0.02 & $2.34 * *$ & 0.02 & $2.74 * *$ & 0.02 & $2.56^{* *}$ \\
\hline Education & -0.001 & -0.41 & -0.001 & -0.61 & -0.002 & -0.89 & -0.002 & -0.75 \\
\hline Economic Growth & 0.03 & 0.63 & 0.26 & $5.49 * *$ & 0.07 & 1.47 & 0.28 & $6.15^{* *}$ \\
\hline Region & -0.07 & -0.25 & 0.30 & $3.07 * *$ & -0.11 & -0.35 & 0.28 & $2.97 * *$ \\
\hline Colonial Legacy & 0.42 & 1.29 & 0.35 & $2.99 * *$ & 0.56 & 1.61 & 0.42 & $3.64 * *$ \\
\hline Constant & -0.62 & -1.40 & -2.57 & -6.70 & -1.06 & -2.39 & -2.97 & -7.64 \\
\hline Diagnostic Statistics & \multicolumn{2}{|c|}{$\begin{array}{c}\text { Wald } \chi_{7}^{2}=16.91 \\
(p \text {-value }=0.01) \\
\text { Overall } R^{2}=0.27\end{array}$} & \multicolumn{2}{|c|}{$\begin{array}{c}\text { Wald } \chi_{7}^{2}=114.91 \\
(p \text {-value }=0.00) \\
\text { Log likelihood }=99.95\end{array}$} & \multicolumn{2}{|c|}{$\begin{array}{c}\text { Wald } \chi_{8}^{2}=41.28 \\
(p \text {-value }=0.00) \\
\text { Overall } R^{2}=0.24\end{array}$} & \multicolumn{2}{|c|}{$\begin{array}{c}\text { Wald } \chi_{8}^{2}=138.45 \\
(p \text {-value }=0.00) \\
\text { Log likelihood }=105.15\end{array}$} \\
\hline
\end{tabular}

Note. $* *$ Coefficient statistically significant at $5 \%$; Coefficient statistically significant at $10 \%$.

Among the other explanatory variables, tax revenues, economic development and European colonial legacy appear to have positive effects on the composite measure of quality of governance (Table 1), which is in line with a priori expected signs. However, education is generally not significant (indeed has a negative coefficient against the composite value of governance). This is surprising since human capital is expected to impact governance quality. One plausible explanation is that the individual variables may not be acting in isolation but in concert with each other. In other words, the effect of education on governance is being moderated by the other variables, which is not being captured by the results. There appears to be some evidence that the quality of governance is better in South Asia over East Asia, which could be due to socio-cultural or other differences not accounted by the other explanatory variables.

The effects of population size on the quality of governance and its six components generally appear to be negative, which is contrary to the a priori expected sign. The literature holds that there should be economies of scale effect of establishing effective institutions. However, this study finds a diseconomies of scale effect, which is plausible considering that the sample used in this study includes the world's top two most populous countries (China and India) and three other countries (Indonesia, Pakistan and Bangladesh) that are also ranked among the world's top 10 most populous countries. Due to huge populations, government resources per capita are stretched thin in several countries in the sample, which may explain the negative effect of huge population on quality of governance, and hence the diseconomies of scale effect.

Table 2 summarizes the detailed results from Tables A2-A7 and shows similar results with respect to foreign aid. The effects of multilateral aid on each one of the six components of governance are statistically significant and positive except in the RE model for regulatory quality (Table A5). The effects of bilateral aid on these components are, however, either insignificant or negative except in the case of government effectiveness in the FGLS model and regulatory quality in the RE model (Table A4 and A5). These results lend credence to the 
hypothesis that multilateral aid is more effective than bilateral aid in promoting the quality of governance in recipient countries, because multilateral aid is often tied to the recipient countries' commitment to promotion of institutional quality. Bilateral aid on the other hand is often dictated by geo-political strategic interest of donor countries, which may have no effect or even negative effect on the quality of governance.

Table 2. Summary of detailed results (refer to appendix Tables A2-A7)

\begin{tabular}{|c|c|c|c|c|c|c|c|c|c|c|c|c|}
\hline & \multicolumn{2}{|c|}{$\begin{array}{c}\text { Voice and } \\
\text { Accountability }\end{array}$} & \multicolumn{2}{|c|}{$\begin{array}{l}\text { Political } \\
\text { Stability }\end{array}$} & \multicolumn{2}{|c|}{$\begin{array}{c}\text { Government } \\
\text { Effectiveness }\end{array}$} & \multicolumn{2}{|c|}{$\begin{array}{c}\text { Regulatory } \\
\text { Quality }\end{array}$} & \multicolumn{2}{|c|}{ Rule of Law } & \multicolumn{2}{|c|}{$\begin{array}{l}\text { Control of } \\
\text { Corruption }\end{array}$} \\
\hline & $\mathrm{RE}$ & FGLS & $\mathrm{RE}$ & FGLS & $\mathrm{RE}$ & FGLS & $\mathrm{RE}$ & FGLS & $\mathrm{RE}$ & FGLS & $\mathrm{RE}$ & FGLS \\
\hline Multilateral Aid & $+^{*}$ & $+{ }^{*}$ & $++^{*}$ & $+^{*}$ & $+^{*}$ & $++^{*}$ & NS & $t^{*}$ & $+^{*}$ & $+^{*}$ & $++^{*}$ & $+^{*}$ \\
\hline Bilateral Aid & NS & NS & NS & NS & NS & $+^{*}$ & $+^{*}$ & NS & $-{ }^{*}$ & NS & NS & NS \\
\hline Population & NS & $t^{*}$ & $-{ }^{*}$ & $-{ }^{*}$ & NS & $+^{*}$ & NS & NS & NS & $-{ }^{*}$ & $-{ }^{*}$ & NS \\
\hline Tax Revenues & $+^{*}$ & $+^{*}$ & $+^{*}$ & NS & NS & $+^{*}$ & $+^{*}$ & $+^{*}$ & NS & NS & NS & NS \\
\hline Education & NS & $+^{*}$ & NS & NS & $-{ }^{*}$ & NS & $-^{*}$ & NS & NS & NS & NS & NS \\
\hline Economic Growth & $+{ }^{*}$ & NS & NS & $+^{*}$ & $+^{*}$ & $+^{*}$ & $+^{*}$ & $+^{*}$ & NS & $+^{*}$ & NS & $+{ }^{*}$ \\
\hline Region & NS & NS & NS & NS & NS & $+^{*}$ & NS & NS & NS & $+^{*}$ & NS & NS \\
\hline Colonial Legacy & $++^{*}$ & NS & NS & NS & $+^{*}$ & $+{ }^{*}$ & NS & NS & $++^{*}$ & $+^{*}$ & NS & NS \\
\hline
\end{tabular}

Note. $+{ }^{*}$ denotes statistically significant coefficient with positive sign; $-^{*}$ denotes statistically significant coefficient with negative sign; NS denotes statistically insignificant coefficient.

The overall diagnostic statistics (measured by Wald $\chi^{2}$, overall $\mathrm{R}^{2}$ and $\log$ likelihood statistics) came out generally satisfactory.

\section{Conclusions and Future Research}

This study very clearly establishes a positive relationship between aid and governance. The findings of the study are important, based as it is on a sample of 14 countries, which constitute a highly populated region of the developing world and account for a significant proportion of the global foreign aid. The results of the study add to our understanding of the role of foreign aid vis-à-vis governance and add weight to the body of literature arguing for the beneficial effect of aid on governance. This is especially important since earlier research findings on the association of aid to governance quality are not conclusive and indeed conflicting. Specifically, this research establishes the efficacy of multilateral aid vis-à-vis bilateral aid in its positive influence on governance.

As all similar studies, this study suffers from the inherent limitation of sample selection and the results are not necessarily generalizable to other regions/countries. However, if the findings especially that of the differential impact of multilateral aid vis-à-vis bilateral aid are replicated in other studies, it can have significant policy implications for donor countries and institutions.

Future researchers may consider expanding the estimation model by including additional explanatory variables such as ethnic heterogeneity and civil strife which may have a bearing on governance quality.

A suggested follow up to a study of foreign aid's effect on governance would be to analyze the impact of governance to a country's economic growth. We suspect though that once again the results may not be conclusive since the effect is likely to vary by each country's industrial profile. Some industries are likely to be more sensitive to governance quality than others and thus depending on the mix of a host country's industries, the effect on growth may vary by country, unless controls for governance sensitivity of industry are included in the model.

\section{References}

Ali, A., \& Isse, S. (2003). Determinants of Economic Corruption: A Cross-Country Comparison. Cato Journal, 22(3), 449-466.

Asongu, S. A. (2013). Fighting corruption in Africa: Do existing corruption-control levels matter? International Journal of Development Issues, 12(1), 36-52. http://dx.doi.org/10.1108/14468951311322109

Bräutigam, D. (2000). Aid Dependence and Governance. EGDI Secretariat, Department for International, Development Cooperation SE-103 39 Stockholm, Sweden.

Bräutigam, D., \& Knack, S. (2004). Foreign Aid, Institutions, and Governance in Sub-Saharan Africa. Economic Development and Cultural Change, 52(2), 255-285. http://dx.doi.org/10.1086/380592 
Charron, N. (2011). Exploring the Impact of Foreign Aid on Corruption: Has the Anti-Corruption Movement Been Effective? The Developing Economies, 49(1), 66-88. http://dx.doi.org/10.1111/j.1746-1049.2010.00122.x

Chenery, H. B. (1965). Trade, Aid and Economic Development. In Robock, \& Soloman (Eds.), International Development (p. 187). New York: Oceana Publications.

Collier, P. (2007). The bottom billion: Why the poorest countries are failing and what can be done about it? New York: Oxford University Press.

Dunning, J. H. (1992). Governments, Markets, and Multinational Enterprises: Some Emerging Issues. The International Trade Journal, 7(1), 1-14. http://dx.doi.org/10.1080/08853909208523753

Dunning, T. (2004). Conditioning the effects of aid: Cold war politics, donor credibility, and democracy in Africa. International Organization, 58(2), 409-423. http://dx.doi.org/10.1017/S0020818304582073

Ear, S. (2007). Does Aid Dependence Worsen Governance? International Public Management Journal, 10(3), 259-286. http://dx.doi.org/10.1080/10967490701515580

Goldsmith, A. (2000). Foreign Aid and Statehood in Africa. African Economic Policy Discussion Paper Number 47. Belfer Center for Science \& International Affairs, John F. Kennedy School of Government, Harvard University.

Goldsmith, A. (2001). Foreign Aid and Statehood in Africa. International Organization, 55(1), 123-148. http://dx.doi.org/10.1162/002081801551432

Griffin, K., \& Enos, J. (1970). Foreign Assistance: Objective and Consequences. Economic Development and Cultural Change, 18(3), 313-326. http://dx.doi.org/10.1086/450435

Harms, P., \& Lutz, M. (2004). The Macroeconomic Effects of Foreign Aid: A Survey. Discussion Paper no. 2004-11, Department of Economics, University of St. Gallen. http://dx.doi.org/10.2139/ssrn.588723

Heckelman, J., \& Knack, S. (2005). Foreign Aid and Market-Liberalizing Reform. World Bank Policy Research Working Paper, No. WPS 3557, Washington, DC: World Bank. http://dx.doi.org/10.1596/1813-9450-3557

Kaufmann, D., Kraay, A., \& Mastruzzi, M. (2010). The Worldwide Governance Indicators: A Summary of Methodology, Data and Analytical Issues. World Bank Policy Research Working Paper, (5430). Retrieved from http://papers.ssrn.com/sol3/papers.cfm?abstract_id=1682130

Knack, S. (2001). Aid Dependence and the Quality of Governance: Cross-Country Empirical Tests. Southern Economic Journal, 68(2), 310-329. http://dx.doi.org/10.2307/1061596

Knack, S., \& Rahman, A. (2007). Donor Fragmentation and Bureaucratic Quality in Aid Recipients. Journal of Development Economics, 83(1), 176-197. http://dx.doi.org/10.1016/j.jdeveco.2006.02.002

Niosi, J. (2002). National Systems of innovations are $\mathrm{x}$-efficient (and x-effective): Why some are slow learners. Research Policy, 31(2), 291-302. http://dx.doi.org/10.1016/S0048-7333(01)00142-1

Okada, K., \& Samreth, S. (2012). The effect of foreign aid on corruption: A quantile regression approach. Economic Letters, 11, 240-243. http://dx.doi.org/10.1016/j.econlet.2011.12.051

Papanek, G. (1972). The Effect of Aid and Other Resource Transfers on Savings and Growth in Less Developed Countries. Economic Journal, 82, 934-950. http://dx.doi.org/10.2307/2230259

Svensson, J. (2000). Foreign Aid and Rent-Seeking. Journal of International Economics, 51(2), 437-461. http://dx.doi.org/10.1016/S0022-1996(99)00014-8

Tavares, J. (2003). Does foreign aid corrupt? Economics Letters, 79, 99-106. http://dx.doi.org/10.1016/S0165-1765(02)00293-8

Weisskopf, T. (1972). The Impact of Foreign Capital Inflow on Domestic Savings in Underdeveloped Countries. Journal of International Economics, 2(1), 25-38. http://dx.doi.org/10.1016/0022-1996(72)90043-8

WGI. (2014). Worldwide Governance Indicators. Retrieved from http://info.worldbank.org/governance/wgi/index.asp

World Bank. (1989). Sub-Saharan Africa: From Crisis to Sustainable Growth. Washington, DC.

World Bank. (2014). World Development Indicators. Retrieved from http://wdi.worldbank.org/tables 


\section{Notes}

Note 1. Details on the WGI data, aggregation method, and interpretations can be found in Kaufmann et al. (2010).

Note 2. Details of the Granger Causality test results are available upon request.

Note 3. Details are available upon request.

\section{Appendix}

Table A1. Foreign aid and quality of governance-South Asia vs. East Asia (1996-2013)

\begin{tabular}{|c|c|c|c|c|}
\hline Country & $\begin{array}{c}\text { Foreign Aid } \\
(\text { ODA/GNI \%) }\end{array}$ & Composite Indicator & Voice and Accountability & Political Stability... \\
\hline Bangladesh & 2.00 & -0.88 & -0.42 & -1.27 \\
\hline Bhutan & 12.57 & 0.11 & -0.77 & 0.81 \\
\hline India & 0.24 & -0.26 & 0.39 & -1.18 \\
\hline Maldives & 4.10 & -0.06 & -0.55 & 0.43 \\
\hline Nepal & 6.28 & -0.79 & -0.64 & -1.53 \\
\hline Pakistan & 1.55 & -1.00 & -0.96 & -2.04 \\
\hline Sri Lanka & 2.26 & -0.34 & -0.37 & -1.23 \\
\hline S. Asia Average & 4.14 & -0.46 & -0.47 & -0.86 \\
\hline Cambodia & 9.11 & -0.83 & -0.92 & -0.57 \\
\hline China & 0.10 & -0.52 & -1.54 & -0.46 \\
\hline Indonesia & 0.58 & -0.62 & -0.26 & -1.28 \\
\hline Lao PDR & 12.95 & -0.98 & -1.53 & -0.26 \\
\hline Malaysia & 0.04 & 0.36 & -0.38 & 0.19 \\
\hline Philippines & 0.45 & -0.39 & 0.03 & -1.31 \\
\hline Vietnam & 3.63 & -0.52 & -1.41 & 0.24 \\
\hline E. Asia Average & 3.84 & -0.50 & -0.86 & -0.49 \\
\hline Global Average & 0.19 & 0.003 & 0.004 & 0.02 \\
\hline Country & Government Effectiveness & Regulatory Quality & Rule of Law & Control of Corruption \\
\hline Bangladesh & -0.72 & -0.93 & -0.88 & -1.06 \\
\hline Bhutan & 0.42 & -0.72 & 0.22 & 0.70 \\
\hline India & -0.07 & -0.35 & 0.08 & -0.44 \\
\hline Maldives & 0.05 & 0.14 & -0.05 & -0.36 \\
\hline Nepal & -0.74 & -0.61 & -0.66 & -0.58 \\
\hline Pakistan & -0.58 & -0.63 & -0.84 & -0.94 \\
\hline Sri Lanka & -0.22 & -0.08 & 0.07 & -0.24 \\
\hline S. Asia Average & -0.27 & -0.45 & -0.29 & -0.42 \\
\hline Cambodia & -0.90 & -0.39 & -1.10 & -1.08 \\
\hline China & 0.01 & -0.24 & -0.43 & -0.48 \\
\hline Indonesia & -0.34 & -0.36 & -0.69 & -0.79 \\
\hline Lao PDR & -0.89 & -1.17 & -0.97 & -1.05 \\
\hline Malaysia & 1.06 & 0.54 & 0.50 & 0.28 \\
\hline Philippines & -0.03 & -0.05 & -0.43 & -0.56 \\
\hline Vietnam & -0.32 & -0.61 & -0.44 & -0.60 \\
\hline E. Asia Average & -0.20 & -0.33 & -0.51 & -0.61 \\
\hline Global Average & -0.005 & -0.006 & 0.005 & 0.004 \\
\hline
\end{tabular}

Data Sources: Worldwide Governance Indicators (2014), World Development Indicators (2014). 
Table A2. Determinants of voice and accountability

\begin{tabular}{|c|c|c|c|c|c|c|c|c|}
\hline & \multicolumn{2}{|c|}{ Random Effects Model } & \multicolumn{2}{|c|}{ Feasible GLS Model } & \multicolumn{2}{|c|}{ Random Effects Model } & \multicolumn{2}{|c|}{ Feasible GLS Model } \\
\hline & Coeff & Z stat & Coeff & Z stat & Coeff & Z stat & Coeff & Z stat \\
\hline Aggregate Aid & 0.02 & $1.87 *$ & 0.03 & $2.72 * *$ & & & & \\
\hline Multilateral Aid & & & & & 0.19 & $4.72 * *$ & 0.11 & $2.37 * *$ \\
\hline Bilateral Aid & & & & & -0.02 & -1.14 & 0.02 & 1.04 \\
\hline Population & 0.001 & 0.02 & 0.09 & $2.13 * *$ & 0.04 & 0.50 & 0.13 & $2.64 * *$ \\
\hline Tax Revenues & 0.02 & 1.40 & 0.02 & $1.95 *$ & 0.02 & $1.75^{*}$ & 0.03 & $2.11 * *$ \\
\hline Education & 0.01 & 1.41 & 0.01 & $2.36 * *$ & 0.004 & 1.12 & 0.01 & $2.4 * *$ \\
\hline Economic Growth & 0.09 & 1.29 & 0.09 & 1.24 & 0.15 & $2.18^{* *}$ & 0.11 & 1.53 \\
\hline Region & 0.33 & 0.99 & 0.19 & 1.34 & 0.31 & 0.87 & 0.20 & 1.41 \\
\hline Colonial Legacy & 0.74 & $1.95^{* *}$ & 0.23 & 1.30 & 0.88 & $2.19 * *$ & 0.26 & 1.50 \\
\hline Constant & -2.57 & -4.36 & -2.56 & -3.9 & -3.27 & -5.53 & -2.94 & -4.31 \\
\hline Diagnostic Statistics & $\begin{array}{r}\text { Wald } \\
\text { (p-va } \\
\text { Overa } \\
\end{array}$ & $\begin{array}{l}6 \\
=20.66 \\
0.00) \\
=0.42 \\
\end{array}$ & $\begin{array}{r}\text { Wal } \\
\text { (p-v } \\
\text { Log lik } \\
\end{array}$ & $\begin{array}{l}6 \\
=29.81 \\
=0.00) \\
d=62.71 \\
\end{array}$ & $\begin{array}{r}{ }^{n} \\
\text { Wald } \\
\text { (p-val } \\
\text { Overal }\end{array}$ & $\begin{array}{l}6 \\
41.79 \\
0.00) \\
=0.37 \\
\end{array}$ & \multicolumn{2}{|c|}{$\begin{aligned} \text { Wald } \chi_{8}^{2} & =34.13 \\
(\mathrm{p}-\mathrm{value} & =0.00)\end{aligned}$} \\
\hline
\end{tabular}

**Coefficient statistically significant at $5 \%$; *Coefficient statistically significant at $10 \%$.

Table A3. Determinants of political stability

\begin{tabular}{|c|c|c|c|c|c|c|c|c|}
\hline & \multicolumn{2}{|c|}{ Random Effects Model } & \multicolumn{2}{|c|}{ Feasible GLS Model } & \multicolumn{2}{|c|}{ Random Effects Model } & \multicolumn{2}{|c|}{ Feasible GLS Model } \\
\hline & Coeff & Z stat & Coeff & Z stat & Coeff & Z stat & Coeff & Z stat \\
\hline Aggregate Aid & -0.002 & -0.08 & 0.01 & 0.36 & & & & \\
\hline Multilateral Aid & & & & & 0.19 & $2.34 * *$ & 0.16 & $1.87^{*}$ \\
\hline Bilateral Aid & & & & & -0.04 & -1.63 & -0.02 & -0.64 \\
\hline Population & -0.27 & $-2.87 * *$ & -0.21 & $-4.28 * *$ & -0.23 & $-2.25 * *$ & -0.17 & $-3.12 * *$ \\
\hline Tax Revenues & 0.06 & $2.11^{* *}$ & 0.00 & 0.00 & 0.06 & $2.30^{* *}$ & -0.002 & -0.10 \\
\hline Education & 0.002 & 0.32 & -0.01 & -1.02 & 0.001 & 0.2 & -0.01 & -1.25 \\
\hline Economic Growth & -0.02 & -0.13 & 0.45 & $3.96 * *$ & 0.02 & 0.16 & 0.54 & $4.73 * *$ \\
\hline Region & -0.32 & -0.83 & 0.03 & 0.18 & -0.36 & -0.87 & -0.06 & -0.31 \\
\hline Colonial Legacy & -0.41 & -0.94 & -0.42 & $-2.14 * *$ & -0.25 & -0.53 & -0.19 & -0.97 \\
\hline Constant & 0.05 & 0.06 & -2.55 & -2.82 & -0.59 & -0.58 & -3.52 & -3.51 \\
\hline Diagnostic Statistics & $\begin{array}{r}{ }^{n} \\
\text { Wald } \\
\text { (p-va } \\
\text { Overa }\end{array}$ & $\begin{array}{l} \\
24.85 \\
0.00) \\
=0.52\end{array}$ & $\begin{array}{r}\text { Wald } \\
(\mathrm{p}-\mathrm{v} \\
\text { Log lik }\end{array}$ & $\begin{array}{l}16 \\
159.57 \\
=0.00) \\
d=-7.23\end{array}$ & $\begin{array}{l}\text { Wald } \\
\text { (p-va } \\
\text { Overa }\end{array}$ & $\begin{array}{l}6 \\
29.26 \\
0.00) \\
=0.53\end{array}$ & $\begin{array}{r}\text { Wald } \\
(\mathrm{p}-\mathrm{v} \\
\text { Log lik }\end{array}$ & $\begin{array}{l}6 \\
200.09 \\
0.00) \\
d=-9.41\end{array}$ \\
\hline
\end{tabular}

**Coefficient statistically significant at $5 \%$; ${ }^{*}$ Coefficient statistically significant at $10 \%$.

Table A4. Determinants of government effectiveness

\begin{tabular}{|c|c|c|c|c|c|c|c|c|}
\hline & \multicolumn{2}{|c|}{ Random Effects Model } & \multicolumn{2}{|c|}{ Feasible GLS Model } & \multicolumn{2}{|c|}{ Random Effects Model } & \multicolumn{2}{|c|}{ Feasible GLS Model } \\
\hline & Coeff & Z stat & Coeff & Z stat & Coeff & Z stat & Coeff & Z stat \\
\hline Aggregate Aid & 0.031 & $3.36^{* *}$ & 0.05 & $5.36^{* *}$ & & & & \\
\hline Multilateral Aid & & & & & 0.20 & $6.35^{* *}$ & 0.12 & $2.86^{* *}$ \\
\hline Bilateral Aid & & & & & -0.01 & -0.52 & 0.04 & $3.25^{* *}$ \\
\hline Population & -0.07 & -0.99 & 0.02 & 0.73 & -0.03 & -0.39 & 0.05 & $2.04 * *$ \\
\hline Tax Revenues & 0.003 & 0.3 & 0.02 & $2.21 * *$ & 0.01 & 0.61 & 0.03 & $2.92 * *$ \\
\hline Education & -0.01 & -1.63 & -0.01 & $-1.89 *$ & -0.01 & $-2.32 * *$ & -0.002 & -0.87 \\
\hline Economic Growth & 0.12 & $2.09 * *$ & 0.35 & $5.94 * *$ & 0.17 & $3.24 * *$ & 0.43 & $7.3 * *$ \\
\hline Region & -0.19 & -0.65 & 0.00 & 0.03 & -0.21 & -0.78 & 0.22 & $1.94 *$ \\
\hline Colonial Legacy & 0.58 & $1.78^{*}$ & 0.16 & 1.30 & 0.71 & $2.32 * *$ & 0.34 & $2.86^{* *}$ \\
\hline Constant & -0.89 & -1.85 & -2.86 & -5.30 & -1.52 & -3.41 & -4.17 & -8.52 \\
\hline \multirow{4}{*}{ Diagnostic Statistics } & \multicolumn{2}{|c|}{$\mathrm{n}=116$} & \multicolumn{2}{|c|}{$\mathrm{n}=116$} & \multicolumn{2}{|c|}{$\mathrm{n}=116$} & \multicolumn{2}{|c|}{$\mathrm{n}=116$} \\
\hline & \multirow{2}{*}{\multicolumn{2}{|c|}{$\begin{array}{l}\text { Wald } \chi^{2}{ }_{7}=31.69 \\
(\text { p-value }=0.00)\end{array}$}} & \multirow{2}{*}{\multicolumn{2}{|c|}{$\begin{aligned} \text { Wald } \chi_{7}^{2} & =82.25 \\
(\mathrm{p} \text {-value } & =0.00)\end{aligned}$}} & \multirow{2}{*}{\multicolumn{2}{|c|}{$\begin{aligned} \text { Wald } \chi_{8}^{2}=71.60 \\
(p-\text { value }=0.00)\end{aligned}$}} & \multirow{2}{*}{\multicolumn{2}{|c|}{$\begin{array}{l}\text { Wald } \chi_{8}^{2}=98.78 \\
(p \text {-value }=0.00)\end{array}$}} \\
\hline & & & & & & & & \\
\hline & \multicolumn{2}{|c|}{ Overall $R^{2}=0.21$} & \multicolumn{2}{|c|}{ Log likelihood $=87.45$} & \multicolumn{2}{|c|}{ Overall $\mathrm{R}^{2}=0.16$} & \multicolumn{2}{|c|}{ Log likelihood $=81.42$} \\
\hline
\end{tabular}

**Coefficient statistically significant at $5 \%$; *Coefficient statistically significant at $10 \%$. 
Table A5. Determinants of regulatory quality

\begin{tabular}{|c|c|c|c|c|c|c|c|c|}
\hline & \multicolumn{2}{|c|}{ Random Effects Model } & \multicolumn{2}{|c|}{ Feasible GLS Model } & \multicolumn{2}{|c|}{ Random Effects Model } & \multicolumn{2}{|c|}{ Feasible GLS Model } \\
\hline & Coeff & Z stat & Coeff & $Z$ stat & Coeff & Z stat & Coeff & Z stat \\
\hline Aggregate Aid & 0.02 & $2.41 * *$ & 0.004 & 0.44 & & & & \\
\hline Multilateral Aid & & & & & 0.023 & 0.64 & 0.09 & $1.89 *$ \\
\hline Bilateral Aid & & & & & 0.022 & $1.86^{*}$ & -0.01 & -1.04 \\
\hline Population & -0.05 & -0.81 & -0.07 & $-2.55 * *$ & -0.05 & -0.79 & -0.05 & -1.61 \\
\hline Tax Revenues & 0.04 & $3.12 * *$ & 0.05 & $3.88 * *$ & 0.04 & $3.10^{* *}$ & 0.05 & $4.11^{* *}$ \\
\hline Education & -0.01 & $-3.12 * *$ & -0.002 & -0.78 & -0.01 & $-3.15 * *$ & -0.003 & -1.00 \\
\hline Economic Growth & 0.13 & $2.15^{* *}$ & 0.19 & $3.00 * *$ & 0.13 & $2.13^{* *}$ & 0.23 & $3.74 * *$ \\
\hline Region & -0.19 & -0.74 & -0.04 & -0.32 & -0.19 & -0.72 & -0.04 & -0.33 \\
\hline Colonial Legacy & 0.48 & 1.63 & -0.02 & -0.18 & 0.48 & 1.57 & 0.09 & 0.65 \\
\hline Constant & -1.09 & -2.31 & -1.65 & -3.11 & -1.08 & -2.17 & -2.15 & -3.92 \\
\hline \multirow[t]{2}{*}{ Diagnostic Statistics } & \multicolumn{2}{|c|}{$\begin{array}{l}\text { Wald } \chi_{7}^{2}=45.33 \\
(\mathrm{p} \text {-value }=0.00)\end{array}$} & \multicolumn{2}{|c|}{$\begin{array}{c}\text { Wald } \chi_{7}^{2}=56.53 \\
(\mathrm{p} \text {-value }=0.00)\end{array}$} & \multicolumn{2}{|c|}{$\begin{array}{l}\text { Wald } \chi_{8}^{2}=45.71 \\
(p-\text { value }=0.00)\end{array}$} & \multicolumn{2}{|c|}{$\begin{array}{l}\text { Wald } \chi_{8}^{2}=71.71 \\
(p-\text { value }=0.00)\end{array}$} \\
\hline & \multicolumn{2}{|c|}{ Overall $\mathrm{R}^{2}=0.15$} & \multicolumn{2}{|c|}{ Log likelihood $=66.81$} & \multicolumn{2}{|c|}{ Overall $\mathrm{R}^{2}=0.15$} & \multicolumn{2}{|c|}{ Log likelihood $=66.75$} \\
\hline
\end{tabular}

**Coefficient statistically significant at $5 \%$; *Coefficient statistically significant at $10 \%$.

Table A6. Determinants of rule of law

\begin{tabular}{|c|c|c|c|c|c|c|c|c|}
\hline & \multicolumn{2}{|c|}{ Random Effects Model } & \multicolumn{2}{|c|}{ Feasible GLS Model } & \multicolumn{2}{|c|}{ Random Effects Model } & \multicolumn{2}{|c|}{ Feasible GLS Model } \\
\hline & Coeff & Z stat & Coeff & Z stat & Coeff & Z stat & Coeff & Z stat \\
\hline Aggregate Aid & 0.001 & 0.09 & 0.01 & 1.03 & & & & \\
\hline Multilateral Aid & & & & & 0.09 & $2.94 * *$ & 0.07 & $1.78^{*}$ \\
\hline Bilateral Aid & & & & & -0.02 & $-1.87 *$ & 0.001 & 0.08 \\
\hline Population & -0.13 & $-1.96^{* *}$ & -0.10 & $-2.73 * *$ & -0.12 & -1.63 & -0.11 & $-2.53 * *$ \\
\hline Tax Revenues & 0.01 & 0.55 & 0.02 & $1.86^{*}$ & 0.01 & 0.71 & 0.02 & 1.56 \\
\hline Education & -0.004 & -1.28 & -0.01 & -1.52 & -0.01 & -1.63 & -0.003 & -0.87 \\
\hline Economic Growth & 0.02 & 0.38 & 0.18 & $2.78 * *$ & 0.05 & 0.9 & 0.18 & $2.63 * *$ \\
\hline Region & 0.06 & 0.21 & 0.58 & $3.70 * *$ & 0.04 & 0.12 & 0.63 & $4.62 * *$ \\
\hline Colonial Legacy & 0.49 & 1.51 & 0.89 & $3.67 * *$ & 0.58 & $1.71^{*}$ & 1.03 & $4.27 * *$ \\
\hline Constant & -0.18 & -0.38 & -1.96 & -3.69 & -0.51 & -1.08 & -2.21 & -4.06 \\
\hline Diagnostic Statistics & \multicolumn{2}{|c|}{$\begin{aligned} \text { Wald } \chi_{7}^{2} & =10.97 \\
(p-\text { value } & =0.14)\end{aligned}$} & \multicolumn{2}{|c|}{$\begin{array}{l}\text { Wald } \chi^{2}{ }_{7}=74.91 \\
(\mathrm{p} \text {-value }=0.00)\end{array}$} & \multicolumn{2}{|c|}{$\begin{array}{l}\text { Wald } \chi_{8}^{2}=21.13 \\
(p \text {-value }=0.01)\end{array}$} & \multicolumn{2}{|c|}{$\begin{array}{c}\text { Wald } \chi_{8}^{2}=116.38 \\
(p \text {-value }=0.00)\end{array}$} \\
\hline
\end{tabular}

**Coefficient statistically significant at $5 \%$; *Coefficient statistically significant at $10 \%$.

Table A7. Determinants of control of corruption

\begin{tabular}{lcccccccc}
\hline & \multicolumn{2}{c}{$\begin{array}{c}\text { Random Effects } \\
\text { Model }\end{array}$} & \multicolumn{2}{c}{ Feasible GLS Model } & \multicolumn{2}{c}{$\begin{array}{c}\text { Random Effects } \\
\text { Model }\end{array}$} & \multicolumn{2}{c}{ Feasible GLS Model } \\
\cline { 2 - 10 } & Coeff & Z stat & Coeff & Z stat & Coeff & Z stat & Coeff & Z stat \\
\hline Aggregate Aid & 0.002 & 0.17 & 0.02 & 1.09 & & & & \\
Multilateral Aid & & & & & 0.12 & $2.83^{* *}$ & 0.15 & $2.72^{* *}$ \\
Bilateral Aid & & & & & -0.02 & -1.56 & -0.01 & -0.74 \\
Population & -0.17 & $-2.09 * *$ & -0.06 & $-1.88^{*}$ & -0.11 & $-1.85^{*}$ & -0.03 & -0.90 \\
Tax Revenues & 0.01 & 0.98 & 0.02 & 1.39 & 0.02 & 1.17 & 0.02 & 1.45 \\
Education & 0.004 & 1.15 & 0.01 & $1.73^{*}$ & 0.004 & 0.98 & 0.004 & 1.10 \\
Economic Growth & -0.09 & -1.35 & 0.18 & $2.52^{* *}$ & -0.05 & -0.68 & 0.17 & $2.39^{* *}$ \\
Region & 0.07 & 0.22 & 0.30 & $2.22^{* *}$ & 0.09 & 0.38 & 0.09 & 0.59 \\
Colonial Legacy & 0.27 & 0.72 & 0.02 & 0.13 & 0.30 & 1.08 & 0.03 & 0.25 \\
Constant & 0.14 & 0.24 & -2.36 & -4.00 & -0.50 & -0.93 & -2.26 & -3.54 \\
\hline
\end{tabular}




\begin{tabular}{ccccc}
\hline & $\mathrm{n}=116$ & $\mathrm{n}=116$ & $\mathrm{n}=116$ & $\mathrm{n}=116$ \\
Diagnostic Statistics & Wald $\chi_{7}^{2}=9.63$ & Wald $\chi_{7}^{2}=35.77$ & Wald $\chi_{8}^{2}=19.85$ & Wald $\chi_{8}^{2}=52.51$ \\
& $(\mathrm{p}$-value $=0.21)$ & $(\mathrm{p}$-value $=0.00)$ & $(\mathrm{p}$-value $=0.01)$ & $(\mathrm{p}$-value $=0.00)$ \\
& Overall $\mathrm{R}^{2}=0.21$ & Log likelihood $=43.67$ & Overall $\mathrm{R}^{2}=0.18$ & Log likelihood $=48.33$ \\
\hline
\end{tabular}

**Coefficient statistically significant at 5\%; *Coefficient statistically significant at $10 \%$.

\section{Copyrights}

Copyright for this article is retained by the author(s), with first publication rights granted to the journal.

This is an open-access article distributed under the terms and conditions of the Creative Commons Attribution license (http://creativecommons.org/licenses/by/3.0/). 